\title{
O cinema gay no Brasil: a representação dos homossexuais em Tatuagem e Hoje Eu Quero Voltar Sozinho ${ }^{1}$
}

\section{Rodrigo Quevedo Fagundes}

Universidade Federal de Santa Maria, Programa de Pós-Graduação em Comunicação, Santa Maria, RS, Brasil

ORCID: https://orcid.org/0000-0002-4188-5103

\section{Flavi Ferreira Lisbôa Filho}

Universidade Federal de Santa Maria, Programa de Pós-Graduação em Comunicação, Santa Maria, RS, Brasil

ORCID: https://orcid.org/0000-0003-4307-9401

\section{Resumo}

Este trabalho analisa a representação dos homossexuais no cinema brasileiro contemporâneo através da perspectiva do Cinema Queer, com foco nos filmes Tatuagem, estreado em 2013 e Hoje eu quero voltar sozinho, estreado em 2014. A metodologia de análise utilizada é o Circuito da Cultura proposto por Johnson no ano de 1999, em conjunto com a análise textual segundo as concepções de Cassetti e Chio publicadas em 1999. Percebemos, com a análise, que existem duas vertentes de representação dos homossexuais no cinema gay brasileiro, uma mais preocupada em seguir os padrões heteronormativos e outra que procura desconstruir essas normas, caracterizando-se por ser queer.

\section{Palavras-chave}

Representação; Cinema; Sexualidade; Identidade; Teoria Queer

\section{Introdução}

Nos últimos anos estávamos acompanhando o crescimento cada vez maior de produções cinematográficas com temática homossexual no Brasil. Porém, com as mudanças políticas dentro do país e o avanço de um conservadorismo em todo o mundo, muitas restrições e censuras têm ocorrido com conteúdos dessa temática. Em 2017, presenciamos o

\footnotetext{
${ }^{1}$ Este trabalho foi apresentado no XVI Congresso IBERCOM, Faculdad de Comunicación y Lenguaje, Pontificia Universidad Javeriana, Bogotá, 27-29 de novembro de 2019.
} 
desmonte da exposição Queermuseu no Santander Cultural, em Porto Alegre, devido à crítica de alguns grupos que alegavam que a mostra promovia pedofilia e zoofilia (G1 RS, 2017). Acompanhamos também diversos boicotes feitos por esses grupos conservadores a filmes, novelas e marcas que se atrelavam ou de alguma forma representavam pessoas LGBTI+2. Em 2019, o prefeito da cidade Rio de Janeiro, Marcelo Crivella, buscou a proibição da venda e circulação, na Bienal do Livro do Rio de Janeiro, de uma história em quadrinhos devido a ela conter uma cena de beijo gay (ARAUJO, 2019). E é nesse mesmo ano em que a Ancine (Agência Nacional do Cinema) revogou apoio financeiro para três filmes com temática LGBTI+ no Brasil após ação do presidente Jair Bolsonaro (EXITOÍNA, 2019). Assim, tivemos interesse na forma como são representadas essas identidades e de que forma elas contribuíam para uma construção social no país.

Para compreender como se dá a representação dos homossexuais procuramos nos basear em uma comparação entre dois filmes. Essa comparação veio pelo interesse na Teoria Queer e no Cinema Queer, que procura uma quebra de paradigmas de forma mais explícita. No Cinema Queer, se enquadram filmes que contestam discursos que legitimam a heteronormatividade. A partir da escolha de dois filmes diferentes na sua forma de narrar a homossexualidade, procuramos, então, traçar reflexões sobre o Cinema Queer no Brasil. Através da comparação podemos perceber melhor como esses filmes buscam ou não contestar os discursos de heteronormatividade.

Segundo dados do Grupo Gay da Bahia, que divulga anualmente um relatório de assassinatos de homossexuais (LGBTI+) no Brasil, somente em 2018 foram registradas 420 mortes de integrantes da população homoafetiva e transexual por homicídio ou suicídio decorrente da discriminação (HERMANSON, 2019). Com base nesses dados, podemos ver que o número de assassinatos por homofobia e transfobia só têm aumentado ao longo dos anos. Em 2015 foram registrados 315 casos, em 2016 foram 343 e em 2017 foi o ápice, com 445 vítimas. E esses números podem ser ainda maiores, pois eles só contabilizam dados a partir de notícias de jornal e internet. Uma das formas de combater esse tipo de violência é fornecer informação e educação sexual para jovens, além da visibilidade que é necessária para essa comunidade, ensinando respeito aos homossexuais à população. Essa visibilidade, no entanto, pode acontecer de diversas formas e por vezes reforça uma visão preconceituosa e heteronormativa, por isso achamos importante estudar o cinema como

\footnotetext{
2 A escolha dessa sigla ao invés das diversas outras existentes para descrever essa comunidade foi devido a utilização dela no slogan da Parada do Orgulho LGBTI+ de São Paulo, considerada a maior parada do mundo, no ano de 2018: "Poder para LGBTI+, Nosso Voto, Nossa Voz".
} 
forma de representação. 0 cinema é uma mídia que pode catalisar opiniões e a forma como conduz sua narrativa pode ajudar na luta pelos direitos homossexuais.

\section{Representação e identidade de gênero}

É necessário, antes de refletir sobre temas como gênero e sexualidade, entender mais sobre como são formadas as tais identidades de gênero e o que suas representações afetam em sua formação. Kathryn Woodward (2014), no livro Identidade e Diferença: a perspectiva dos estudos culturais, considera a identidade como uma formação de diversos fatores, como a diferença, o fator social e a simbologia. Para Woodward (2014), uma identidade depende de outra para existir. É na relação de diferença que ela se afirma, se distinguindo daquilo que ela não é. "Assim, a construção da identidade é tanto simbólica quanto social. A luta para afirmar as diferentes identidades têm causas e consequências materiais" (WOODWARD, 2014, p. 10).

Relacionando essas concepções de formações de identidade com os homossexuais e o movimento LGBTI+ podemos criar diversas conexões. Primeiro já no modelo binário de hétero/homo podemos ver a necessidade de negação de um para a existência do outro. Ao normatizar um modo de identidade e tentar fixá-lo, já se pressupõe o descarte de outro. Assim, os que se encaixam dentro dessa norma seguiriam o que é "correto" e os que não se encaixam seriam os diferentes, "incorretos". Como vemos atualmente, a tentativa de muitas pessoas de só validar os discursos e as relações heterossexuais seria uma luta para afirmar essa identidade. Gays, lésbicas, bissexuais, travestis, transexuais seriam o "outro" a ser contestado para a afirmação.

Temos que levar em conta também o poder que possui uma representação. "Todas as práticas de significação que produzem significados envolvem relações de poder, incluindo o poder para definir quem é incluído e quem é excluído" (WOODWARD, 2014, p. 18). Isso fomenta a desigualdade social e faz com que alguns grupos sejam excluídos e estigmatizados. A falta de representatividade da mídia brasileira mostra como a homossexualidade é tratado como desviante e anormal. A heteronormatividade é o que rege os meios de comunicação. Os homossexuais, quando representados, devem seguir essas normas também. Um homem gay e uma mulher lésbica devem seguir os padrões de masculinidade e feminilidade. Quando não são retratados assim, são motivos de piada e 
alívio cômico para o enredo. Quando falamos de travestis e transexuais a representatividade é ainda menor e mais pejorativa.

A globalização está muito ligada com esse processo de mudança de identidade na modernidade. Não temos mais uma centralidade ou tradição, que antes pensávamos ser divinamente estabelecidas. Segundo Hall (2005), a identidade é algo formado ao longo do tempo, ela está sempre em processo de formação. Assim, devemos considerar a formação da identidade como um processo de identificação, e não como uma coisa acabada em si.

Essas concepções de identidade formada através de identificações são contrárias ao pensamento de que a identidade de gênero é definida de acordo com o sexo. A contemporaneidade trouxe a possibilidade de visualizarmos uma cultura global e com ela mais diversidade de ideias e concepções. A heteronormatividade é uma visão antiquada de um sujeito que deve ter a sua identidade de acordo com o seu sexo, com aparência, gestos, atitudes em acordo com algo pré-determinado e que o qual deve seguir idêntico a vida inteira. Atualmente, percebemos muito mais a complexidade dessa relação de gênero e sexo, e também que a formação da identidade homossexual acontece em vários níveis de identificação e que elas podem coexistir com outras identidades.

\section{Gênero e sexualidade}

Contribuindo atualmente aos estudos sobre gênero e sexualidade, Judith Butler (2003), em seu livro Problemas de gênero: feminismo e subversão da identidade, discute a dualidade do sexo tratado como uma formação natural e o gênero como algo construído socialmente. Com isso, a autora desmonta um dos princípios da teoria feminista, de ter uma identidade definida para as mulheres. Ela indica uma inexistência desse sujeito ao criticar o modelo binário.

Para Butler (2003), mesmo o gênero sendo uma construção social originado por uma cultura, ele também é determinado e não algo de livre arbítrio. Isso mostra como a cultura da sociedade ainda é uma cultura machista. Para a nossa sociedade, o homem e a mulher devem ser, respectivamente, masculinos e femininos. Um corpo masculino ou feminino deve corresponder com o seu gênero. Então, o gênero tratado como formação de uma cultura pode parecer flutuante, optativo, mas ele é tão determinado quanto o sexo para a biologia.

Para traçar um pensamento sobre sexualidade, foi utilizado como fonte a obra de Foucault (2014) História da Sexualidade 1: a vontade de saber. No livro o autor busca 
explicar o surgimento de discursos sobre o sexo e a sexualidade. No início do século XVII, o sexo era tratado de forma muito banal. Era um assunto que era tratado com naturalidade entre crianças e adultos. Essa visão do sexo acaba sendo encerrada com a força da moral da burguesia vitoriana. A sexualidade passa a ser algo restrito à família conjugal, tendo como a única função a reprodução.

O autor começa então a contestar essa ideia. Para ele, a sexualidade não é de fato silenciada e fadada à ignorância a seu respeito. A isso ele chama de hipótese repressiva. Segundo Foucault (2014), os discursos sobre sexo começam a se multiplicar devido à criação de dispositivos e procedimentos que passam a interrogar e registrar esse tópico. Muito dessa incitação a falar sobre sexo veio do uso do poder sobre ele. Instituições como a Igreja, a Literatura, a Medicina, a Escola, de certa forma obrigavam o indivíduo a falar sobre a prática sexual, seja como forma para se livrar de seus pecados ou para estudos e diagnósticos, visando um controle sobre a população. Foucault (2014) não procurava entender o poder como algum modo de sujeição ou como um sistema de dominação exercido por grupos, elementos e conjunto de instituições; ele via isso como suas formas terminais. 0 poder não é algo que se adquire e ele se exerce em inúmeros pontos.

A partir do século XVIII, é possível distinguir "quatro grandes conjuntos estratégicos, que desenvolvem dispositivos específicos de saber e poder a respeito do sexo" (FOUCAULT, 2014, p.113). Entre eles estão a histerização do corpo da mulher, a pedagogização do sexo da criança, a socialização das condutas de procriação e a psiquiatrização do prazer perverso (FOUCAULT, 2014). A partir daí é criado o dispositivo da sexualidade, para a investigação dos desejos, criando as noções que temos até hoje.

0 que podemos perceber com essa hipótese é que os discursos sobre sexo vêm até hoje sendo construídos através das relações de poder. A Igreja, como um dos maiores órgãos de poder, se apoia em um discurso heteronormativo, onde tudo o que foge dessas normas é considerado heresia, até mesmo tratado como doença. Vale refletir sobre esse uso do poder para o conhecimento sobre sexo. É notória a influência sobre a Medicina, a Literatura e, hoje em dia, podemos ver a influência nos meios de comunicação. A falta de representação de homossexuais, lésbicas, travestis e transexuais mostra ainda esse regime de ocultação do diferente, do que não é considerado "normal", porque isso pode não ser percebido com bons olhos pela maioria da população que considera isso até mesmo um crime. 


\section{História e percurso da Teoria Queer}

A Teoria Queer trouxe outra perspectiva para essa análise. A primeira intenção era somente realizar um estudo sobre a forma como os homossexuais eram representados no cinema brasileiro atualmente. Após a introdução do conceito queer, isso se tornou maior e a análise das representações ficou mais densa e com problemáticas que antes provavelmente teriam passado despercebidas. Essa é a maior função da Teoria Queer: ela procura desconstruir as formas de pensamento tradicionais e abrir espaço para novas discussões, revelando aspectos que antes se mostravam implícitos nos discursos.

A primeira pessoa a utilizar o termo Teoria Queer foi Teresa de Lauretis em 1990, que o criou como forma de denominação para as pesquisas que vinham sendo realizadas sobre gays, lésbicas e todas as outras minorias sexuais e de gênero. Queer significa em português algo estranho ou esquisito. Esse termo é muito utilizado como forma de insulto para homossexuais masculinos, destacando-os como anormais à sociedade heteronormativa. Porém, o termo também foi utilizado durante o início do século XX para designar coisas exóticas de uma forma positiva. Para Souza (2008), isso demonstra como a teoria busca mostrar que nada é estanque, que toda identidade não é constituída de uma essência pura, mas sim por contínuas apropriações.

Podemos definir queer como um conjunto de ideias que propõe uma concepção fluída de identidade. Elas questionam as relações estáveis entre o sexo biológico (cromossômico), o gênero e a orientação sexual. Veem isso como algo construído culturalmente e de caráter não fixo, propondo uma multiplicidade de formas de gênero e de sexo e não só as centradas em um binarismo limitador de hétero/homo, masculino/feminino. Dentro desse conceito, apresentam o poder sexual como o principal motivo dessa existência de fronteiras e divisões sexuais junto com o desejo de ordenação das relações sexuais. Beatriz Preciado (2015, p.30) diz, por exemplo, que "a identidade homossexual é um acidente sistemático produzido pela maquinaria heterossexual, e estigmatizado como antinatural, anormal e abjeta em benefício da estabilidade das práticas de produção do natural".

Desde o final dos anos 1980 e início dos anos 1990, Butler (2003) passa a voltar suas análises para uma reflexão sobre as identidades sexuais. A partir disso, passa a ser vista como uma das principais teóricas queer. Ela focou sua obra na desconstrução do sujeito, passando a conceber o sexo como o resultado de diversos processos discursivos inseridos 
na história e na cultura. "O gênero é, para Butler, uma ficção cultural, o efeito performativo de actos reiterativos" (ALMEIDA, 2004, p.5). 0 trabalho dela é de analisar as identidades como efeitos de discurso, construídos através de instituições e práticas regulatórias que se baseiam em uma visão heteronormativa do mundo. Esse discurso é construído desde o momento do parto, onde já somos designados como menino ou menina e tudo após isso passa a ser controlado por uma lei heterossexual, como quando um menino possui características afeminadas normalmente é insultado de "bicha" e uma menina masculinizada insultada como "sapatão".

Essas práticas discriminatórias são, inclusive, vistas também dentro da comunidade LGBTI+. Gays mais femininos são normalmente tratados com desrespeito ou até mesmo com nojo. 0 mesmo acontece com as lésbicas "machinho" (butch, no termo em inglês). É muito comum ouvir entre os homossexuais expressões como "não curto afeminados" ou denominações de lésbicas como "machorra", "sapa", "sapatão", "caminhoneira”, etc. Isso é a consequência de uma sociedade machista e misógina, onde o feminino é tratado com desprezo e onde também toda mulher ou homem deve ter seus rituais de feminilidade e masculinidade correspondentes ao seu sexo biológico. A discriminação é ainda maior em torno das transexuais e travestis, que são obrigadas pela própria sociedade a passar por diversas transformações e intervenções para serem vistas de acordo com o seu "verdadeiro sexo". Tudo decorrente de uma visão falocêntrica do sexo, onde para ser homem é necessário ter "pau" e para ser mulher é necessário ter uma "buceta", e mesmo com isso as trans ainda correm o risco de ser tratadas como escória e anormais.

Junto com Butler (2003), outros teóricos também começaram a realizar análises dos mecanismos de naturalização do sexo e do gênero e como esses sistemas binários controlam nossa vida em sociedade. Entres os mais importantes estão Sedgwick, Rubin, Warner e Halperin. Em suas análises, Eve Kosofsky Sedgwick (2007) discute sobre uma perspectiva de que a dominação das mulheres e dos homossexuais provêm de uma misoginia e de uma homofobia e de que os binarismos são relacionados e dependem um do outro para basear o seu repúdio e projetar o preconceito. Sedgwick (2007) vê uma ordem sexual controladora, onde a heterossexualidade é beneficiada e tornada natural.

Em 1991, Warner cria o conceito de heteronormatividade, como uma forma de agrupar todas as normas da sexualidade e de gênero, onde comportamentos e identidade sexual devem estar de acordo com o sexo cromossomático de cada sujeito. "Por heteronormatividade entendemos aquelas instituições, estruturas de compreensão e 
orientações práticas que não apenas fazem com que a heterossexualidade pareça coerente ou seja, organizada como sexualidade - mas também que seja privilegiada" (BERLANT; WARNER, 20023 apud MISKOLCI, 2007, p.5). Segundo essa ordem social, todos devem organizar suas vidas conforme um modelo de heterossexualidade.

O que a Teoria Queer procura então é desconstruir essas normas contraditórias, onde uma sexualidade depende da outra mas, ao mesmo tempo, pretende excluí-la. Ela pretende questionar esses métodos de naturalização e não simplesmente eliminá-los. Umas das consequências desses binarismos mostram como a heteronormatividade também tem influência para os homossexuais. 0 que se procura então, seguindo as regras heteronormativas, são homossexuais que despertem entre os héteros expressões como "você não tem jeito de gay" ou "você nem parece lésbica". Esses serão os mais "aceitos" na sociedade.

Além de uma teoria, queer pode ser visto também como uma posição política. É uma manifestação afirmativa da homossexualidade, colocando-se contra todas as formas normativas de sexo, gênero e sexualidade. Algumas vertentes da Teoria Queer incluem também outras pautas em suas críticas, como o aburguesamento liberal de certas comunidades gays e o triunfo de modelos estéticos e eróticos baseado em certos modelos de corpo (ALMEIDA, 2004).

No campo audiovisual, como forma de combater essas estratégias sociais normalizadoras nos filmes, surgiu o Cinema Queer para apresentar personagens e histórias que normalmente não são representados em produtos midiáticos e, quando representados, são feitos através de um olhar heteronormativo e silenciador dos discursos dessas minorias. Daremos maior destaque a história do Cinema Queer, pois esse será o aporte para a classificação e a análise dos filmes selecionados para essa pesquisa.

\section{Percurso metodológico}

Baseado nos Estudos Culturais, será utilizado para a análise dos filmes o Circuito da Cultura proposto por Johnson (1999). Para o referido autor, "é também possível ler os textos como formas de representação desde que se compreenda que estamos sempre analisando a representação de uma representação" (JOHNSON, 2010, p.107). 0 seu Circuito da Cultura se

\footnotetext{
3 BERLANT, Laurent; WARNER, Michael. Sexo em Público. In: JIMÉNEZ, Rafael Manuel Mérida (editor) Sexualidades Transgressoras. Barcelona:Içaria, 2002. p. 229-257.
} 
divide nas seguintes categorias: condições de produção; formas textuais; condições de leitura e culturas vividas/meio social.

Figura 1 - Circuito proposto por Johnson

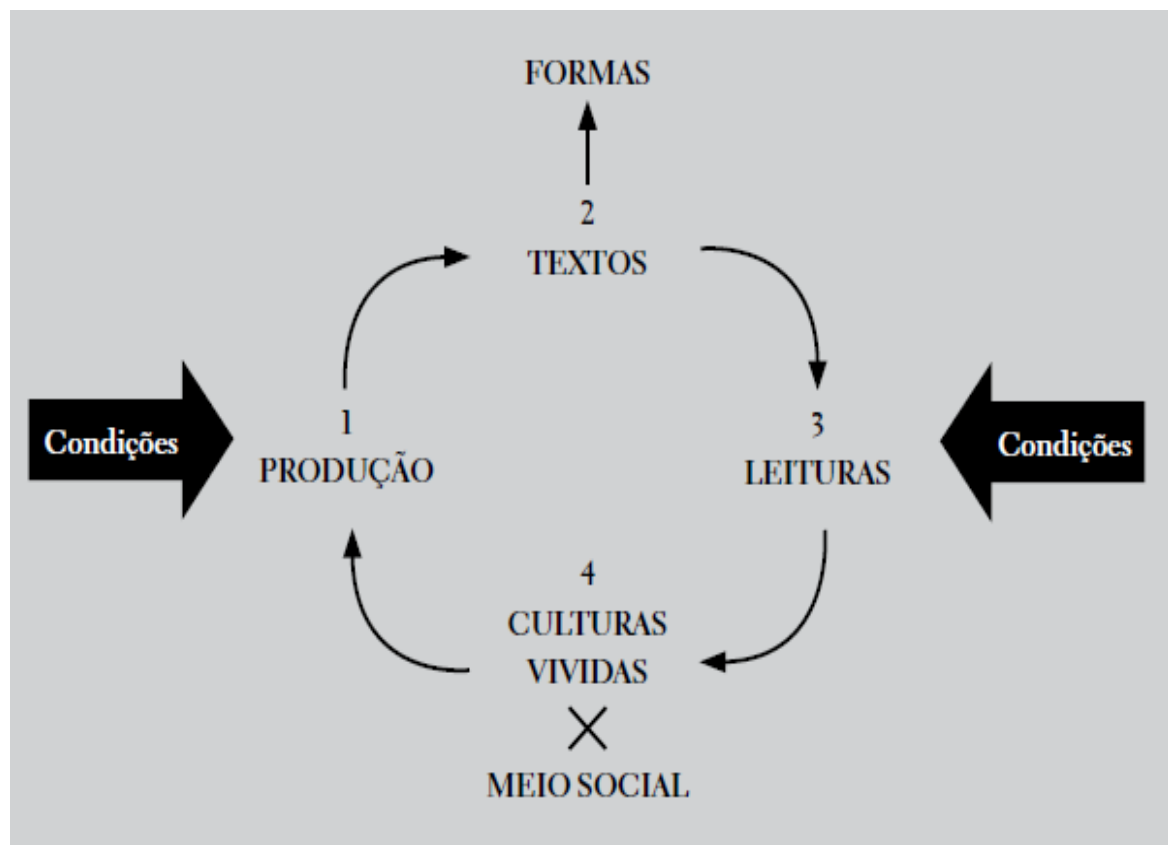

Fonte: 0 que é, afinal, Estudos Culturais? (JOHNSON, 1999, p. 35).

Adaptando este circuito ao objeto de pesquisa, podemos desdobrá-lo em subcategorias. Nas condições de produção, pretendemos analisar também se filmes com esse tipo de temática ainda encontram dificuldades para conseguir apoio e patrocínio de empresas que muitas vezes acham esse assunto irrelevante ou polêmico demais para associar o seu nome. Em formas textuais, incluímos a narrativa cinematográfica e os contextos enunciativos. Nas condições de leitura, pretendemos trazer alguns dados de audiência dos dois filmes, sua popularidade e bilheteria. Isso complementará a pesquisa e influenciará na análise para ver qual tipo de abordagem do tema teve melhor recepção com o público. Por fim, em culturas vividas, adicionamos o contexto social, político, histórico e cultural em relação aos homossexuais.

Para dar conta de analisar a narrativa cinematográfica (o texto em si), será utilizada combinada a metodologia de análise textual segundo as concepções de Cassetti e Chio (1999). Para a análise dos filmes em questão, a metodologia vai ser adaptada de forma a corresponder aos elementos fílmicos. A análise textual, segundo eles, foca nos elementos linguísticos que caracterizam os produtos audiovisuais, os materiais utilizados e os códigos 
(linguísticos, gramaticais, sintáticos, estilísticos, culturais e ideológicos) que presidem o seu tratamento. Ela se configura como uma reconstrução da estrutura e dos processos dos objetos investigados de forma qualitativa.

Como um dos objetivos da análise é apontar as principais diferenças de representação entre os dois filmes, será realizada a interpretação dos seus elementos com base em categorias pré-selecionadas. Criamos quatro categorias de análise baseadas nas propostas por Cassetti e Chio (1999):

- O enredo: análise dos aspectos mais contextuais da história, qual é o eixo narrativo principal e o desenrolar da trama;

- O casal: relação do casal principal, como se tratam, como se portam e os seus diálogos;

- As relações: relação das personagens protagonistas com as suas respectivas famílias e com os seus núcleos de convivência, analisando seus diálogos;

- Elementos complementares ao texto: são analisados elementos como o cenário, trilha sonora, enquadramento e iluminação, mostrando como eles influenciam na narrativa.

Com a realização de todas essas etapas será possível ter um panorama de representações dos filmes e ver qual deles carrega em seu discurso um posicionamento queer. Este posicionamento será determinado pelas definições da própria Teoria Queer, que busca se libertar dos padrões heteronormativos através da desconstrução dessas normas impostas. Com a análise, será possível enxergar quais elementos demonstram atitudes mais fora dos padrões e que não se limitam ou convencionam para ter aceitação da sociedade, mas impõem o respeito de serem tratados com naturalidade, como sempre deveriam ser.

\section{Tatuagem e Hoje eu quero voltar sozinho: uma análise comparativa da representação dos homossexuais}

Para a análise, procuramos, entre os últimos filmes lançados, aqueles que tivessem popularidade e um olhar diferente sobre a homossexualidade, ainda que possuíssem diferentes narrativas e formas de tratar o assunto. Daí a escolha de Tatuagem (2013) e Hoje eu quero voltar sozinho (2014). 
Tatuagem, de Hilton Lacerda, mostra a história de Clécio (Irandhir Silva), líder de uma trupe de teatro/cabaré, localizada no Nordeste do Brasil, que apresentam resistência política por meio de provocação e deboche à ditadura militar em 1978. Clécio conhece Fininha (Jesuíta Barbosa), um soldado de 18 anos, com o qual acaba se envolvendo e, assim, provocando mudanças em ambos. Hoje eu quero voltar sozinho, de Daniel Ribeiro, apresenta Leonardo (Guilherme Lobo), um adolescente cego, que procura por sua independência se livrando da superproteção da mãe. Gabriel (Fábio Audi), um novo aluno na escola, acaba despertando em Leonardo sentimentos que até então para ele pareciam confusos.

Adicionando um contexto social aos filmes, podemos constatar que a temática LGBTI+ carrega muita história consigo. Ela já tem enraizada uma imagem preconceituosa construída durante anos, da perseguição da Igreja Católica até os atuais crimes de ódio, que reproduzem, de certa forma, a sentença de morte de antigamente. Espera-se que filmes com essa temática sejam vistos como polêmicos, embora retratem histórias tão corriqueiras como a de casais heterossexuais. Seguir os padrões heteronormativos para tentar se encaixar, ser aceito na sociedade e conquistar um público maior, não irá combater a discriminação; pelo contrário, somente fará com que ela cresça, pois retratará uma visão limitada que não representa a pluralidade dessa comunidade. Isso gera preconceito contra aqueles que não seguem padrões e que serão perseguidos por isso. 0 cinema pode ser um lugar de visibilidade para essa minoria e essa visibilidade terá maior importância se não mostrar somente um tipo de visão. Os direitos devem ser iguais e a heteronormatividade pode ser desconstruída através da representação cada vez maior de homossexuais, que não precisarão temer o beijo, o toque, o sexo e a nudez diante das câmeras.

Filmes com temática LGBTI+ muitas vezes encontram barreiras para serem produzidos e receberem o apoio ou patrocínio de empresas. Essa dificuldade é um reflexo de um pensamento já enraizado dentro da sociedade brasileira, onde o tema LGBTI+ é considerado polêmico e que não agrada a maioria do público pagante.

O que podemos constatar é que Tatuagem e Hoje eu quero voltar sozinho foram sustentados através de editais que são quase todos os mesmos. Esses filmes não apelam tanta para uma popularidade nem tem como objetivo atingir o mainstream nacional, que é ocupado em sua maioria por filmes de comédia, romance ou produções com atores "globais". Isso faz com que grandes empresas privadas não queiram apoiar por medo da falta de retorno para a marca e de como o filme será recebido pelo público. 0 tema acaba, então, de certa forma influenciando nas condições de produção, o que acabará tendo consequências 
no resultado final do filme. É visível que, no Brasil, a homossexualidade ainda é tratada como polêmica e que o preconceito é muito grande. Por isso, para esses filmes, em relação a outros com apelo mais popular, a dificuldade aumenta na hora de buscar incentivos, patrocínios, apoios, acabando por terem que optar por uma produção mais independente, de baixo custo, não tendo também muitas condições de divulgação. Isso acarreta na exibição dos filmes em ciclos mais alternativos, dependendo, às vezes, de manifestações do público para a estreia em algumas cidades, como será visto na análise das condições de leitura.

Hoje eu quero voltar sozinho é um filme que não pretende ser sobre homossexualidade, mas ele aborda esse tema num meio termo, como se estivesse com receio de se aprofundar para não causar polêmica, e acaba tratando somente como uma descoberta sexual. Não são tomadas posições políticas nem são discutidos os temas dentro da realidade contemporânea. 0 contexto atual pode ajudar a construir o filme, mas ele não toma proporções dentro dele.

Em Tatuagem a diversidade de etnias e sexualidade é maior, embora ainda seja representada uma maioria de corpos magros. 0 filme tem a característica de ser regional e apresentar personagens mais pobres da Recife de 1978. Ele retrata uma época de ditadura, em que a censura era muito forte e o Chão de Estrelas ${ }^{4}$ representa uma forma de liberdade dentro dessa sociedade. Os dois filmes tratam de liberdade, um em um âmbito mais pessoal e outro focando na liberdade de expressão, liberdade de corpos e sexual. Os problemas enfrentados são mais densos do que os dramas adolescentes do primeiro. Aqui eles têm que lidar com, além de descobertas pessoais, problemas familiares, abusos dentro do quartel, com a opressão da ditadura e a construção de um novo tempo. As apresentações realizadas no Chão de Estrelas são uma crítica à sociedade da época e aos seus ideais. Com a "Polka do $\mathrm{Cu}$ " eles procuram mostrar que todos são iguais e que de certa forma estão unidos pelo "cu", que todo mundo tem, simbolizando a democracia e a liberdade. "O símbolo da liberdade é o cu, que é democrático e todo mundo tem" (TATUAGEM, 2013), como diz em passagem no filme.

Tatuagem trata da homossexualidade sem pudores. Clécio e Paulete (Rodrigo García) ${ }^{5}$ são interpretados de forma mais efeminada, e isso não parece ser um problema para os outros personagens. Na maioria das apresentações da trupe, eles usam maquiagem e roupas femininas, por vezes apresentando-se como mulheres e outras vezes como homens.

\footnotetext{
4 Nome dado à trupe de teatro/cabaré liderada por Clécio.

5 Integrante do Chão de Estrelas.
} 
Isso mostra uma posição queer, de transição entre os gêneros, não querendo se limitar à heteronormatividade.

Embora o filme mostre a realidade da ditadura em 1978, os temas tratados ainda são bem atuais. Continuamos a buscar por igualdade e mais liberdade sexual. A nudez e o sexo ainda são tratados como tabu e a representação de sexo entre dois homens ainda choca e causa polêmica para muita gente.

$\mathrm{Na}$ análise do casal, é posto em vista seu relacionamento, como se tratam, como é construída sua relação diante da câmera e todo o resto que pode dizer respeito aos dois personagens principais juntos. Em Hoje eu quero voltar sozinho (2014), o casal principal é formado por dois meninos adolescentes em pleno descobrimento sexual. Leonardo nunca beijou ninguém e Gabriel aparentemente nunca tinha se sentido atraído por um garoto antes. Para os dois tudo aquilo é novo. No começo, o afeto começa a ser construído pelo destaque no toque entre eles, quando Leo segura no braço de Gabriel para guiá-lo, por exemplo. Não fica evidente que algum deles já se sinta atraído, mas aquilo faz com que eles fiquem mais próximos. Em todas as cenas o toque é sempre focado em plano detalhe, dando importância para aqueles gestos sutis que vão construindo a intimidade entre os dois.

Figura 2 - Cena de Gabriel e Leonardo no cinema

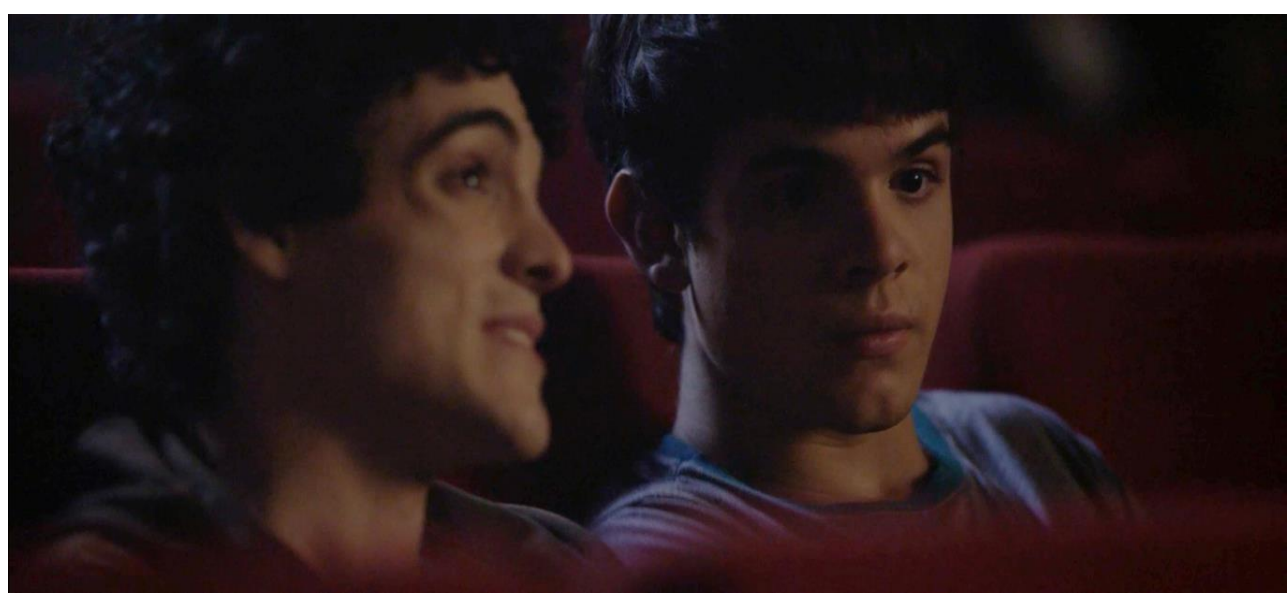

Fonte: Hoje eu quero voltar sozinho (2014).

Os dois protagonistas do filme não quebram nenhum padrão heteronormativo e também não procuram desconstruir ele. Leo e Gabriel são dois meninos cis-gêneros que tem seus comportamentos relacionados ao seu sexo biológico, não apresentando nenhum traço de feminilidade. São jovens de classe média, aparentemente de acordo com os padrões e que 
tem problemas comuns de adolescentes. A questão da homossexualidade só é trazida no filme pelos colegas de Leo e Gabriel que ficam brincando que eles são um casal, mas sem nunca citar termos como gay, veado, homossexual, etc. 0 filme tem por objetivo somente contar uma história de amor e descoberta adolescente, sem levantar questões mais polêmicas.

Tatuagem tem como casal principal Clécio e Fininha. Clécio é um homem mais velho, mais maduro e mais bem resolvido que Fininha. Quando Fininha o vê pela primeira vez, no Chão de Estrela, quando Clécio está apresentando uma canção vestido de mulher, ele fica deslumbrado pela segurança que Clécio passa. A tensão sexual entre eles já surge nesse instante. A cena de dança entre os dois quebra padrões de gênero, mostrando dois homens dançando juntos, com Fininha ocupando a posição que seria de uma mulher. Fica claro a segurança de Clécio de sua sexualidade e em querer quebrar os padrões de gênero.

O beijo e o sexo são tratados de forma mais explícita. A nudez no sexo é mostrada de forma natural, não como função de chocar e sim como forma de não a tratar como tabu. Fininha é passivo no sexo, indo contra ao pensamento de que o mais "másculo" seria o ativo de uma relação, desconstruindo um estereótipo. Fininha se apaixona pela liberdade que tem com Clécio e assume diferentes expressões quando está com ele e quando está no quartel. 0 relacionamento tem a caraterística de ser aberto, mais uma vez indo contra os padrões heteronormativos. Falam que não tem contrato com nada e que não pertencem a ninguém.

Figura 3 - Cena de beijo entre Clécio e Fininha

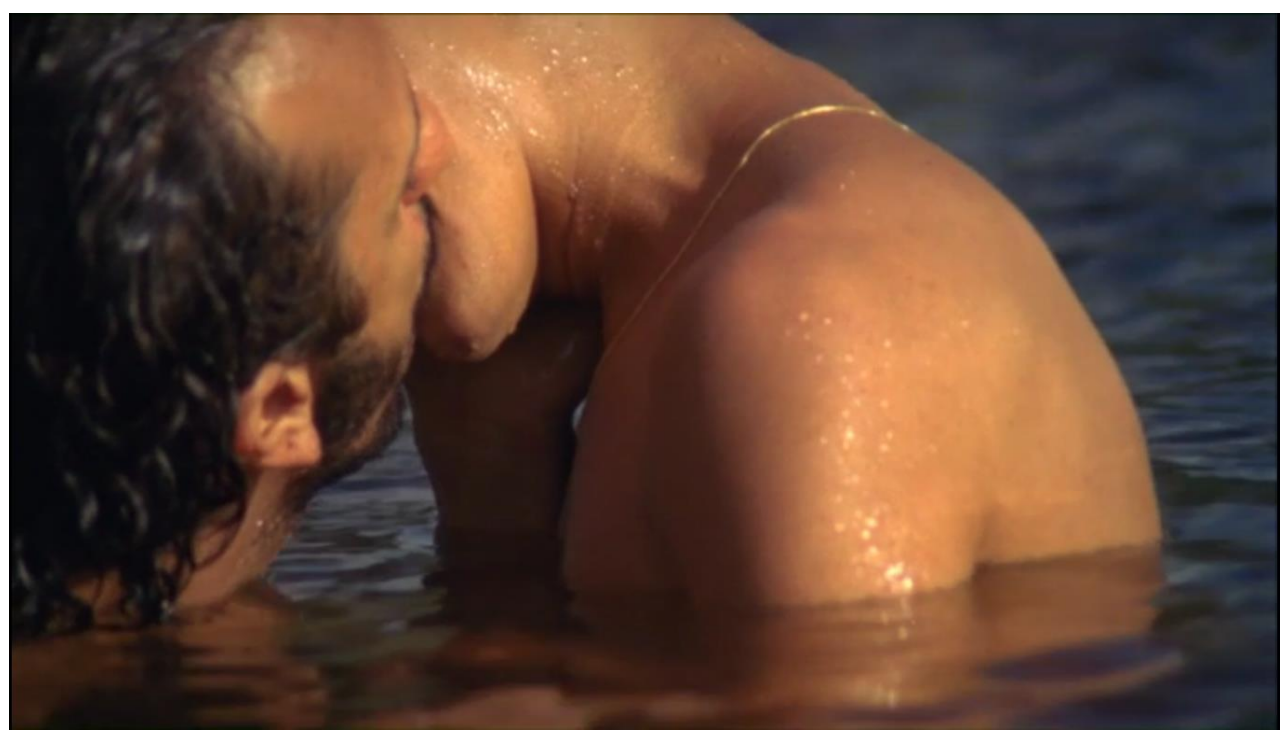

Fonte: Tatuagem (2013). 
Nesse filme, a homossexualidade é mais abordada. Os personagens se afirmam como "veados" e já estão resolvidos com a sua sexualidade, com exceção de Fininha que vai se descobrindo com o decorrer do filme. Clécio tem trejeitos femininos e utiliza dessa feminilidade em suas apresentações, utilizando maquiagem, roupas e acessórios considerados femininos. Os dois fazem parte de uma realidade mais pobre e underground, não apresentam uma beleza eurocêntrica, mas são bonitos dentro dos padrões societais. 0 sexo não é tratado de nenhuma forma como um tabu, nem na linguagem que utilizam expressões como "pau duro", "rola", "meter", e é representado com mais detalhes nas cenas. A homossexualidade também não é o tema central do filme, e sim a história de amor entre Clécio e Fininha, que tem como plano de fundo a opressão sofrida na época de ditadura.

Partimos, então, para analisar o relacionamento dos protagonistas com os demais personagens e núcleos. A família de Leo, em Hoje eu quero voltar sozinho, se apresenta como superprotetora e preocupada com o filho. A mãe dele quer controlar e saber de todos os passos que o filho dá, enquanto o pai faz o papel de "companheiro" do filho, procurando levar em conta a opinião dele e seus pedidos. Essa superproteção da mãe é relacionada com a deficiência visual de Leonardo, pois ele reclama que os pais o tratam diferente de como outros pais tratam os filhos adolescentes. No filme, Leo não revela para os pais que é gay, e acaba que os problemas com a sua família só sejam de querer que eles lhe deem mais liberdade e independência.

Giovana (Tess Amorim) é a melhor amiga de Leo desde a infância. Ela apresenta uma paixão platônica por ele, o que acaba se revelando somente um amor de adolescência e uma confusão de sentimentos na sua cabeça, que também começa uma paixão por Gabriel. Gi é a única para quem Leo revela que está apaixonado por Gabriel. De início, ela fica confusa e não entende muito bem aquela situação, pois sempre tinha imaginado o amigo de outra forma. Ela, porém, acaba por incentivar a relação dos dois amigos. Isso a torna ainda mais próxima dos dois, por ser a única pessoa de confiança que sabe sobre o relacionamento deles.

Na escola, a relação que eles têm com os outros colegas é de antagonismo, um grupo de meninos fica fazendo brincadeiras com Leo e Gabriel. São os típicos adolescentes populares e engraçados da turma que fazem bullying com os diferentes que possuem uma característica marcante que eles possam caçoar, como a deficiência visual de Leo e depois a relação íntima que ele tem com Gabriel.

Fininha, em Tatuagem (2013), tem uma família muito religiosa. Ele vai mostrando ao longo do filme que se sente incomodado com isso, não tendo o mesmo pensamento. Fininha 
mantém, em sua cidade natal, uma relação com uma namorada, o que mostra que ele ainda não aceitou sua sexualidade e procura nela uma forma de afirmar sua heterossexualidade. Quando já está mais confiante e amadurecido depois de ter ficado com Clécio, Fininha termina com a namorada e começa a confrontar os ideais de sua família. Isso é um modo dele se desvencilhar do passado para poder construir uma nova pessoa dali para frente, uma pessoa mais livre dos padrões que lhe eram impostos. Os pais de Clécio não aparecem em nenhum momento do filme. Ele só fala que seu pai era militar e que o obrigou a servir o exército para ver se "virava homem". 0 contato entre eles parece ser quase inexistente a não ser pelo comentário que Clécio faz dizendo que o seu pai o convidou para jantar em família. Ele não fez questão de comparecer ao jantar e isso mostra que ele não liga mais para opinião do pai, pois já é um homem independente que toma as próprias decisões e tem seus próprios valores. Clécio formou sua própria família com Deusa (Sylvia Prado), sua exmulher, e o filho deles. Ele é assumidamente gay para eles e ambos tratam isso com naturalidade, sem estranheza. Deusa é uma protetora de Clécio e uma confidente para ele. 0 filho deles é criado nesse meio liberal do Chão de Estrelas. Eles não reprimem que o filho veja seus espetáculos com nudez e abordagens sexuais. Em seus valores, ele não vê problema na homossexualidade do pai. Foi ensinado a só ver problema em quem reprime e dissemina o ódio, não em quem quer quebrar os padrões, as normas, e problematiza a opressão para que não haja mais preconceito ou discriminação.

Clécio é visto como um líder e mestre por toda a sua trupe. Os membros da trupe se tratam todos como uma grande família, com uma liberdade e sem pudores para relações sexuais. Quando Fininha passa a andar com eles, também é tratado assim. Quando estão juntos parece ser um mundo à parte, onde não se vive seguindo as doutrinas da sociedade e onde o preconceito e a intolerância não existem. Todos são tratados como iguais.

No quartel, Fininha enfrenta os insultos do soldado Gusmão (Ariclenes Barroso), que acaba tendo um desejo enrustido por Fininha. Gusmão e o tenente com que Fininha se relacionava dentro do quartel representam a hipocrisia do exército. 0 exército recriminava (e ainda recrimina) os homossexuais, mas os próprios militares mantinham relações com outros homens dentro do quartel. É desse sistema que Fininha se liberta ao encontrar Clécio e poder finalmente afirmar-se pelo que é, ser quem ele quer ser.

Hoje eu quero voltar sozinho (2014) apresenta em suas cenas cores mais claras, em tons pastéis, o que dá ao filme um ar de leveza e romantismo. Em seus enquadramentos, opta por utilizar planos detalhe para realçar os toques entre Leo e Gabriel e a simplicidade 
desses gestos que, para os dois, significa muito. 0 filme toma cuidado para não enquadrar a nudez frontal na cena. A música no filme tem como função aproximar os protagonistas. Enquanto Leo só escuta música clássica, Gabriel apresenta para ele outros estilos musicais e sua música favorita. 0 fato de Leo só escutar música clássica representa a sua ingenuidade, estando preso em um mundo e protegido do resto. Gabriel representa a abertura de um novo mundo para ele ao ensiná-lo sobre outras músicas.

Figura 4 - Cena Leonardo e Giovana

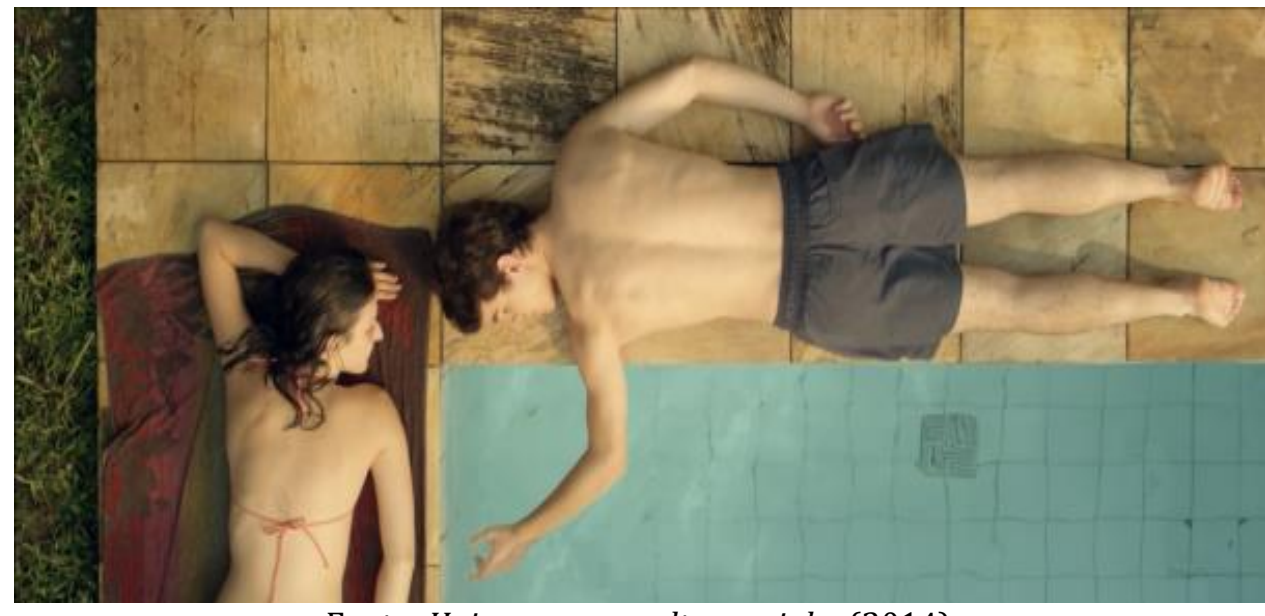

Fonte: Hoje eu quero voltar sozinho (2014).

Figura 5 - Cena Gabriel e Leonardo

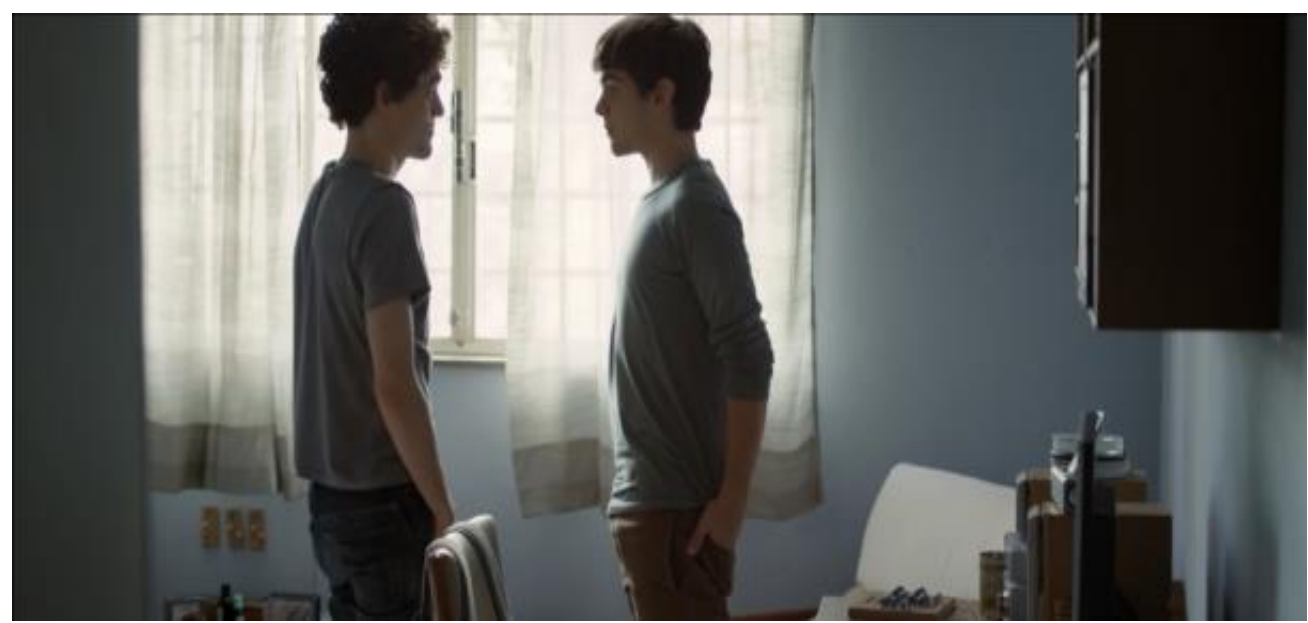

Fonte: Hoje eu quero voltar sozinho (2014). 
Figura 6 - Cena de toque em plano detalhe 1

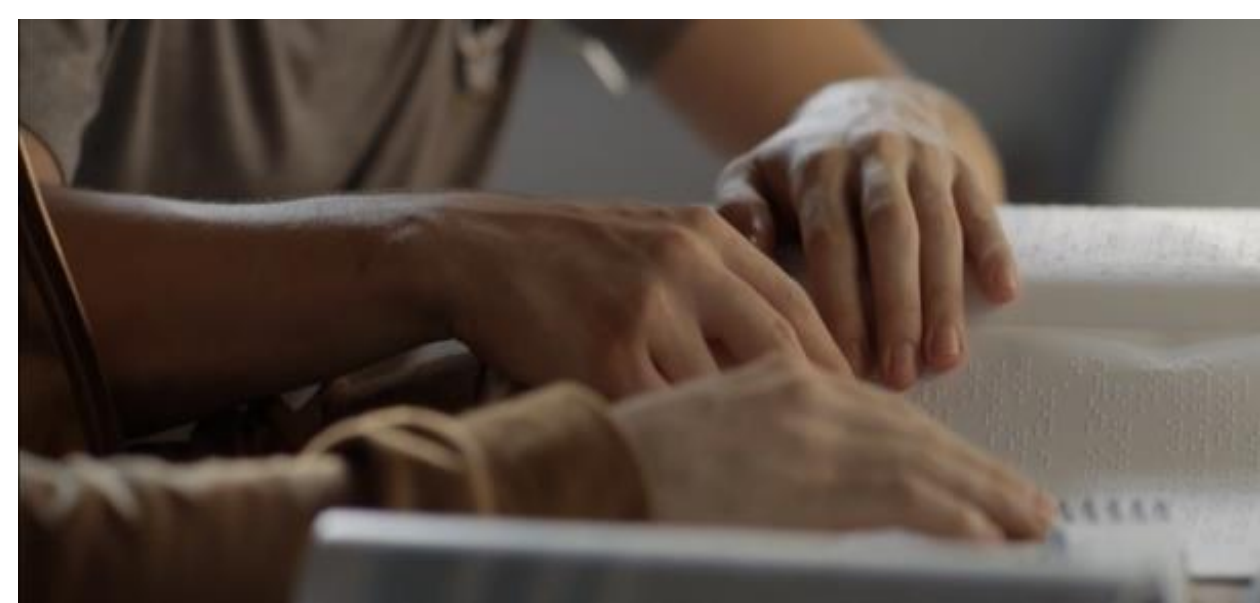

Fonte: Hoje eu quero voltar sozinho (2014).

Figura 7 - Cena de toque em plano detalhe 2

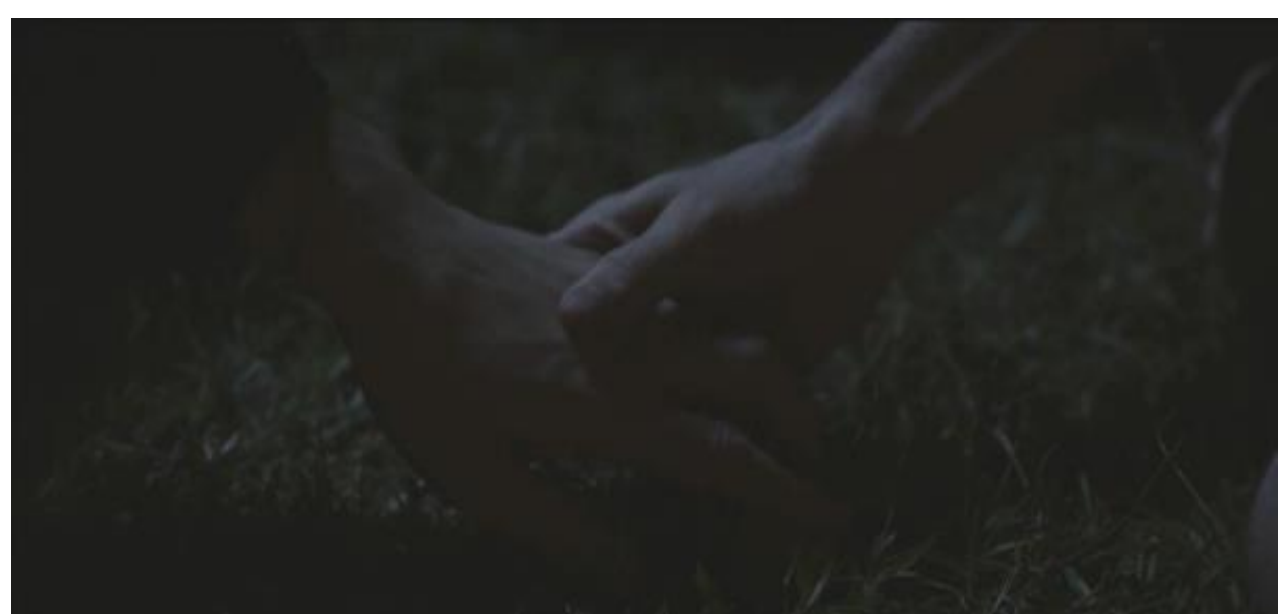

Fonte: Hoje eu quero voltar sozinho (2014).

Figura 8 - Cena do vestiário 1

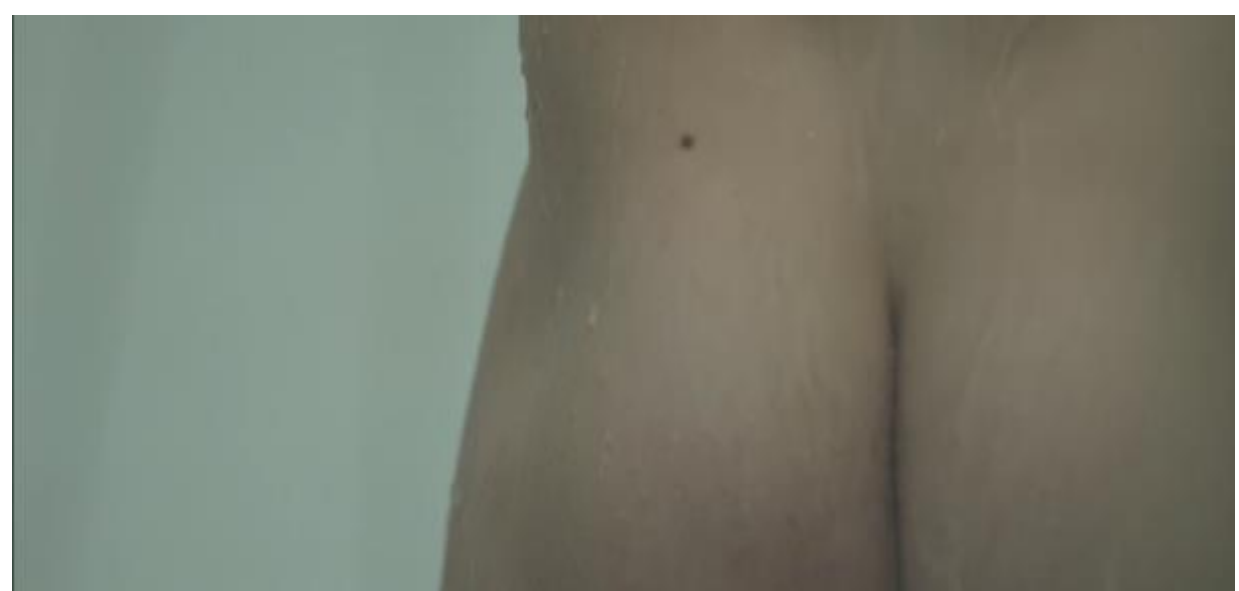

Fonte: Hoje eu quero voltar sozinho (2014). 
Figura 9 - Cena do vestiário 2

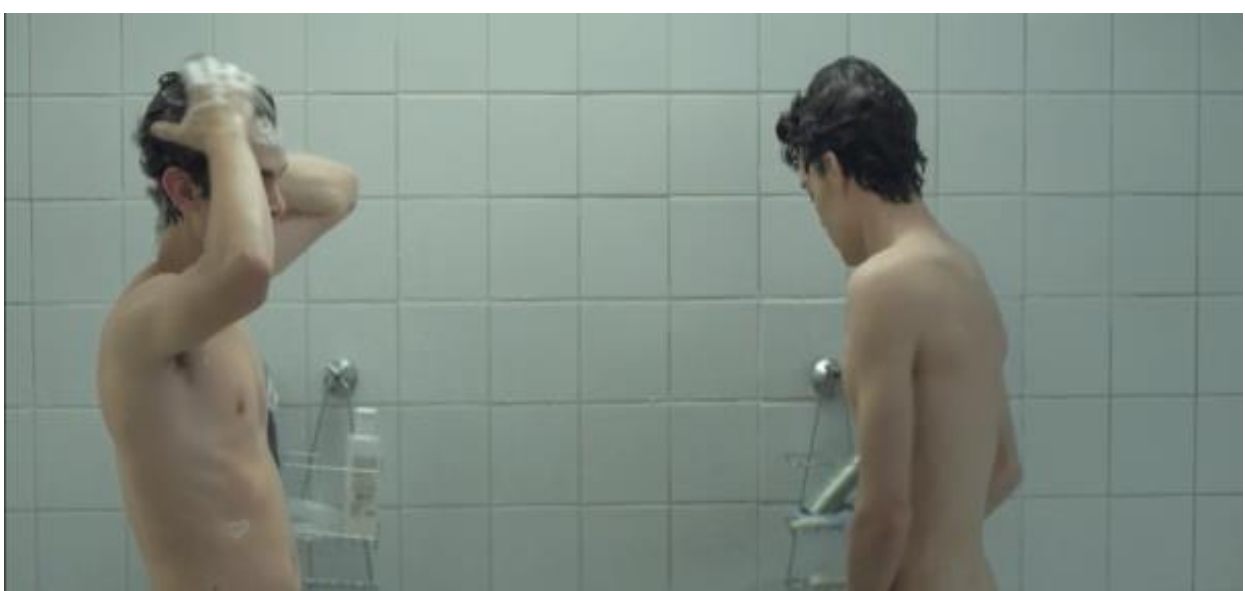

Fonte: Hoje eu quero voltar sozinho (2014).

As cores em Tatuagem variam entre as cenas para se adaptarem ao tom da narrativa. Quando é mostrado o Chão de Estrelas ou o casarão, as cenas são compostas por diversas cores em tons quentes, que fazem contraponto às cenas no quartel, mais monocromáticas e frias. 0 objetivo aqui é mostrar a visão limitada de quem oprime e o mundo de quem se submete a essas normas, sem diversidade de cores, ao contrário daqueles que procuram viver em liberdade e sem preconceitos, mais alegres e confiantes. Os corpos são valorizados pelos enquadramentos e a nudez tem destaque nas cenas, recurso para torná-la natural assim como qualquer outro elemento no filme. 0 diretor opta por não mostrar a violência dos militares quando eles invadem o Chão de Estrelas, como forma de mostrar que é aquele tipo de ato que deve ser oprimido, suprimido com o corte, o fim.

Os cenários não apresentam luxo, mostrando que se tratam de personagens pobres de periferia. No Chão de Estrelas há certa ludicidade, como se fosse um lugar à parte do mundo, com um pensamento à frente do seu tempo. As músicas que são apresentadas no filme apelam mais para uma brasilidade, com sons muito característicos, valorizando a cultura regional. 
Figura 10 - Cena do Chão de Estrelas

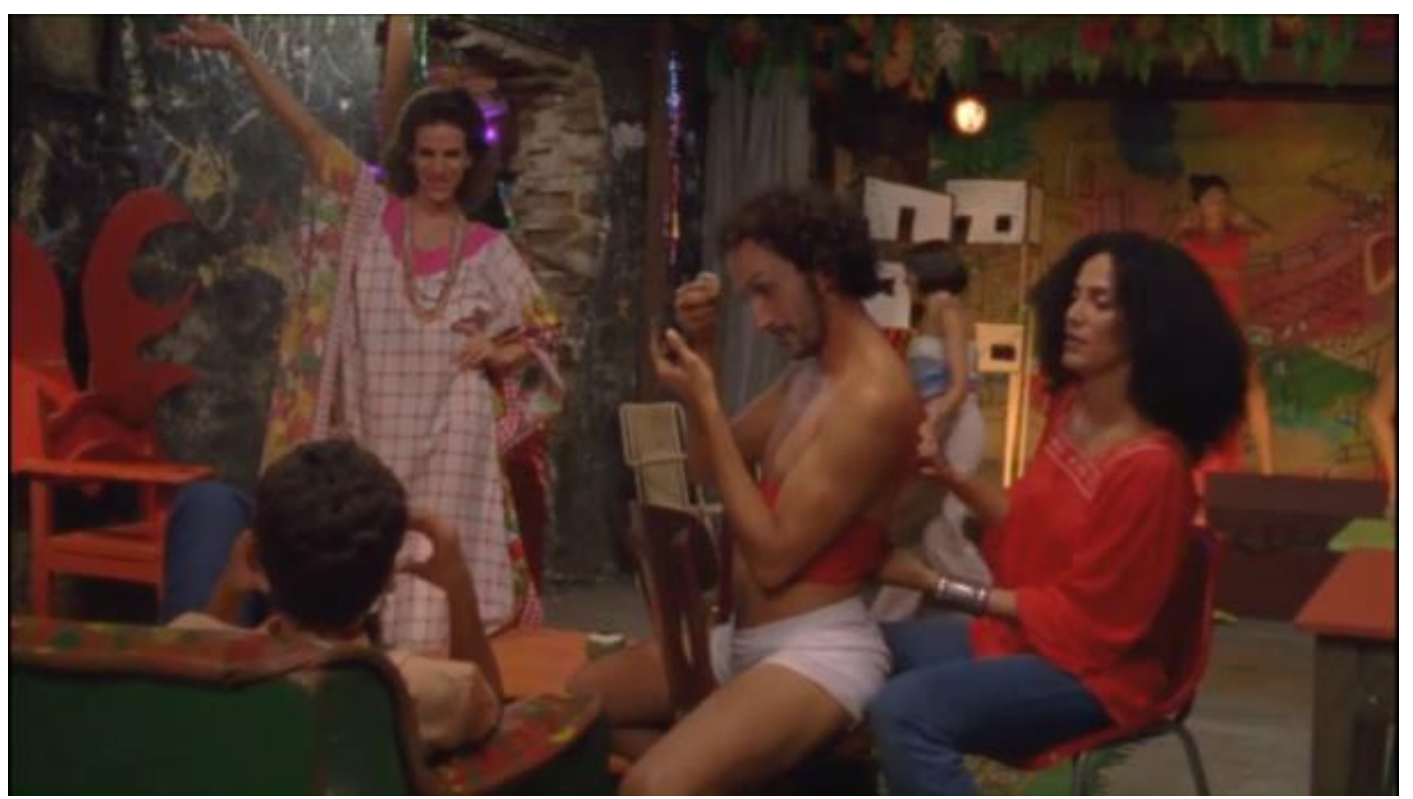

Fonte: Tatuagem (2013).

Figura 11 - Cena do casarão da trupe

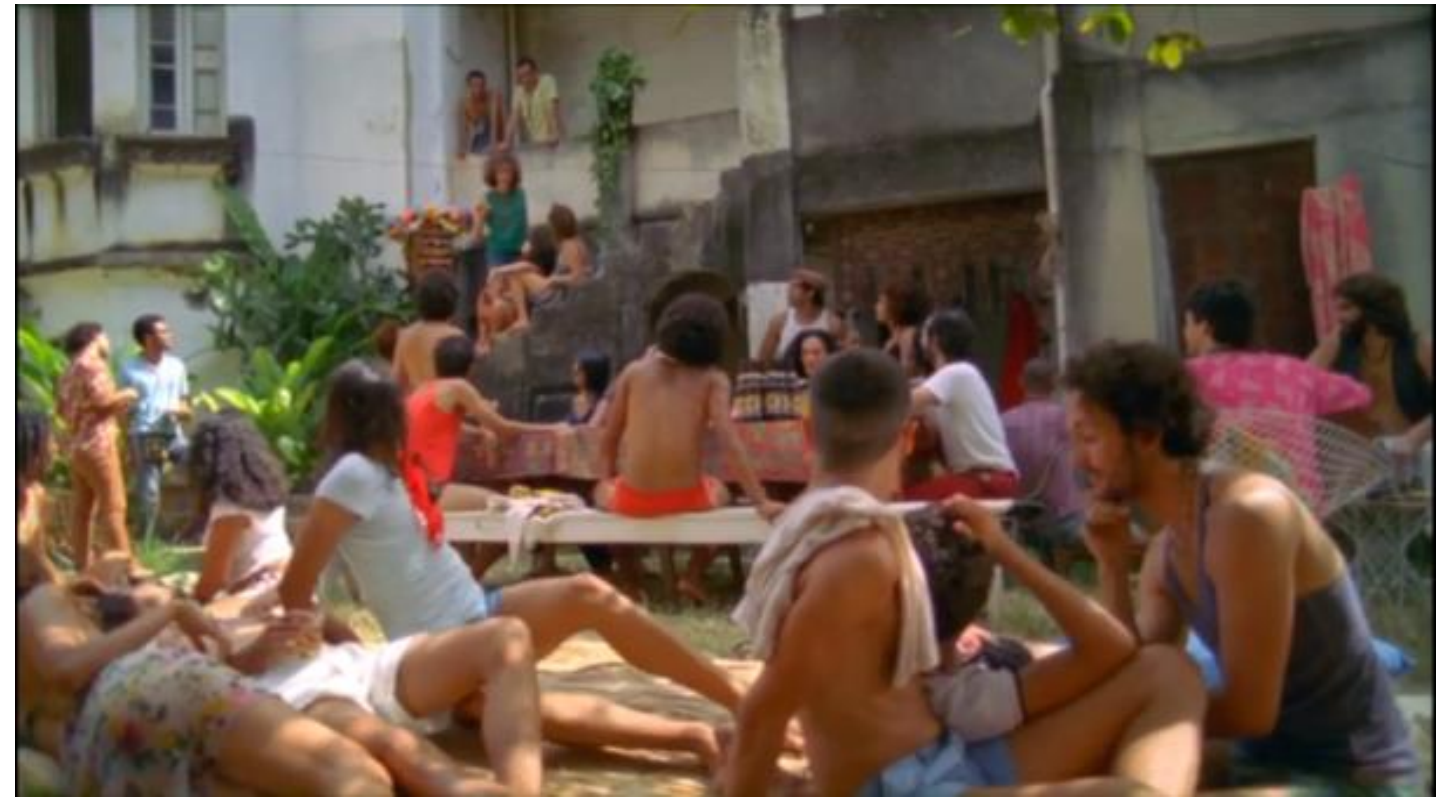

Fonte: Tatuagem (2013). 
Figura 12 - Cena de Fininha no quartel

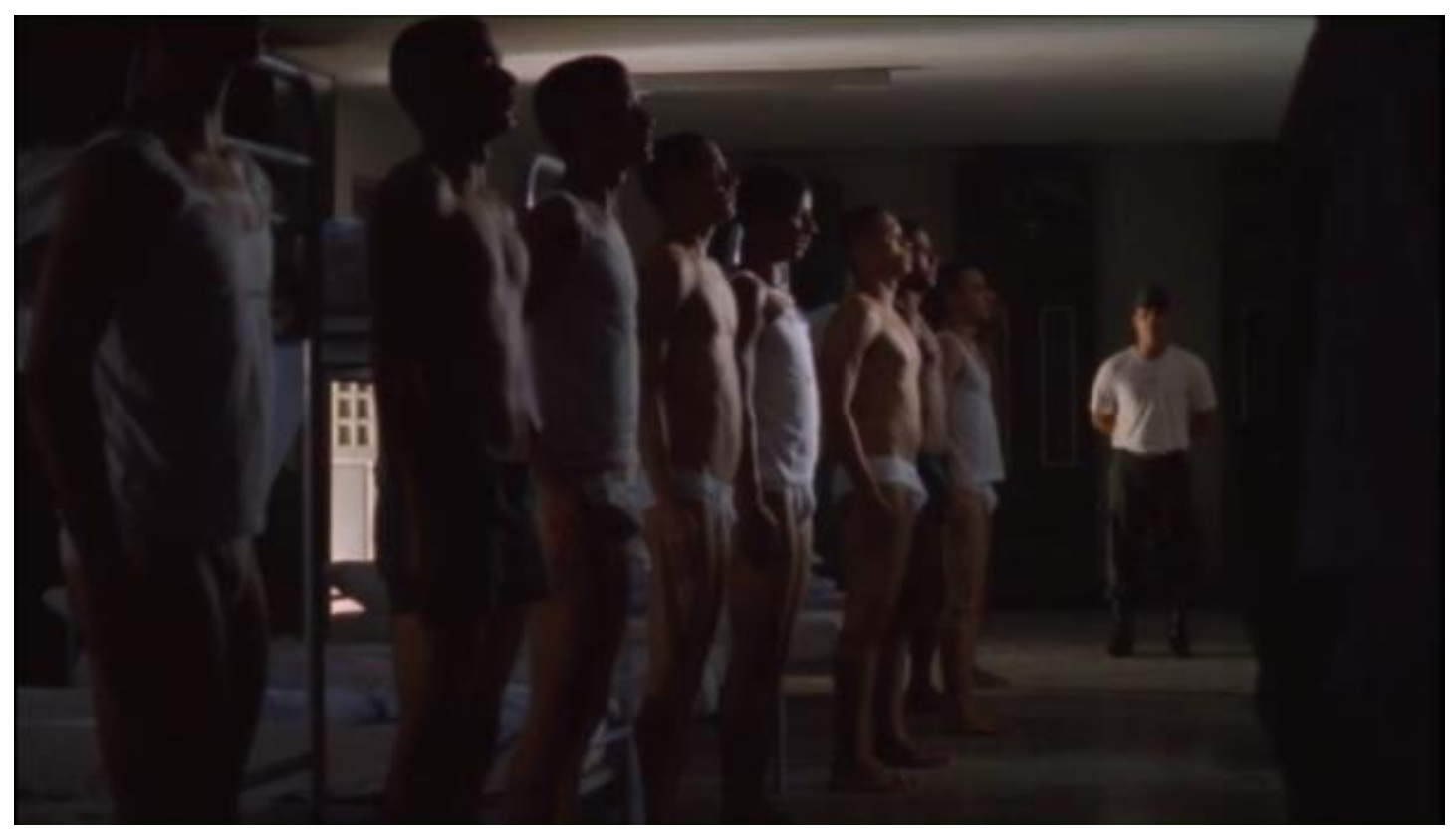

Fonte: Tatuagem (2013).

Figura 13 - Cena de Fininha com a família

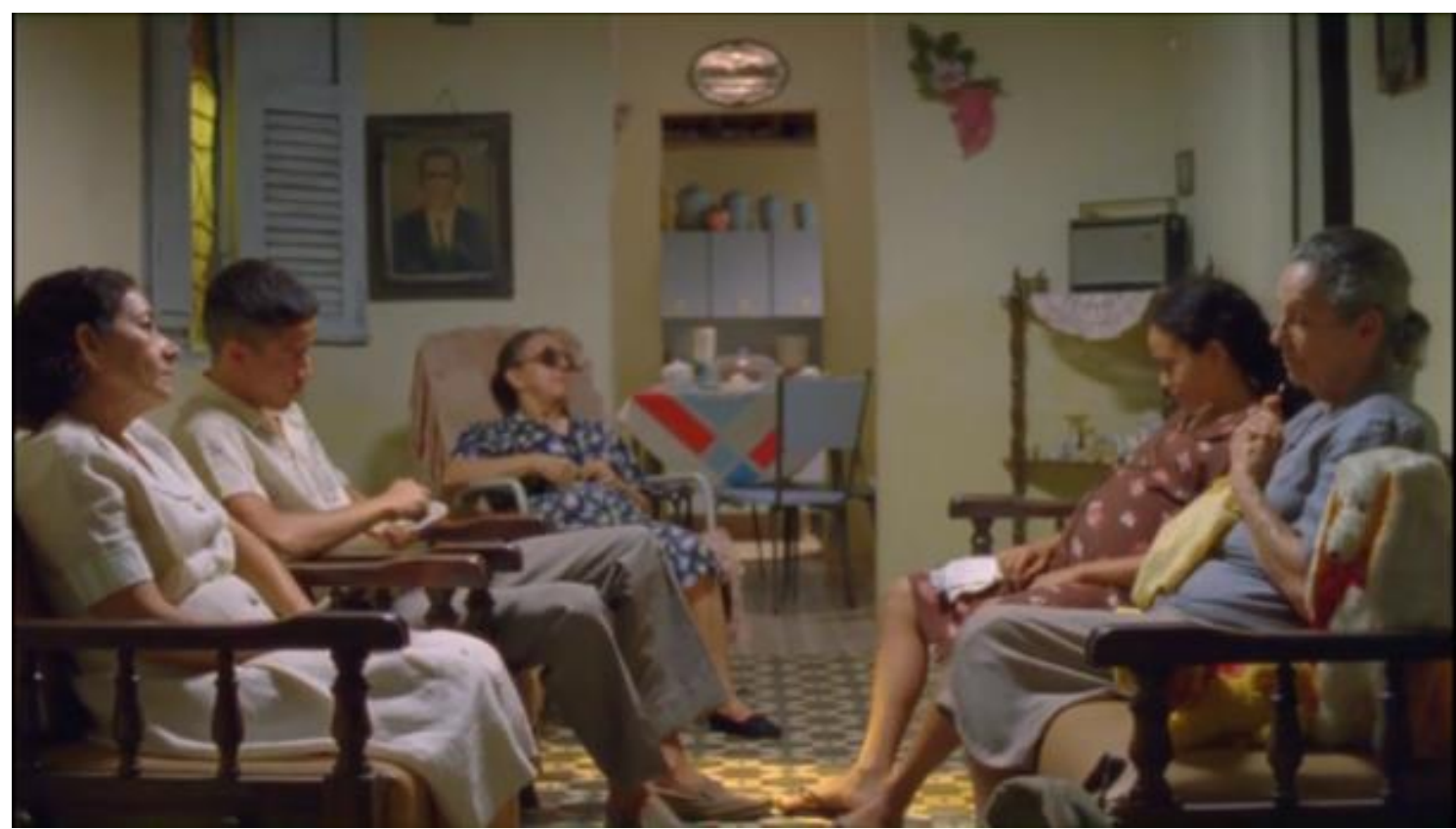

Fonte: Tatuagem (2013). 
Figura 14 - Cena de apresentação da trupe

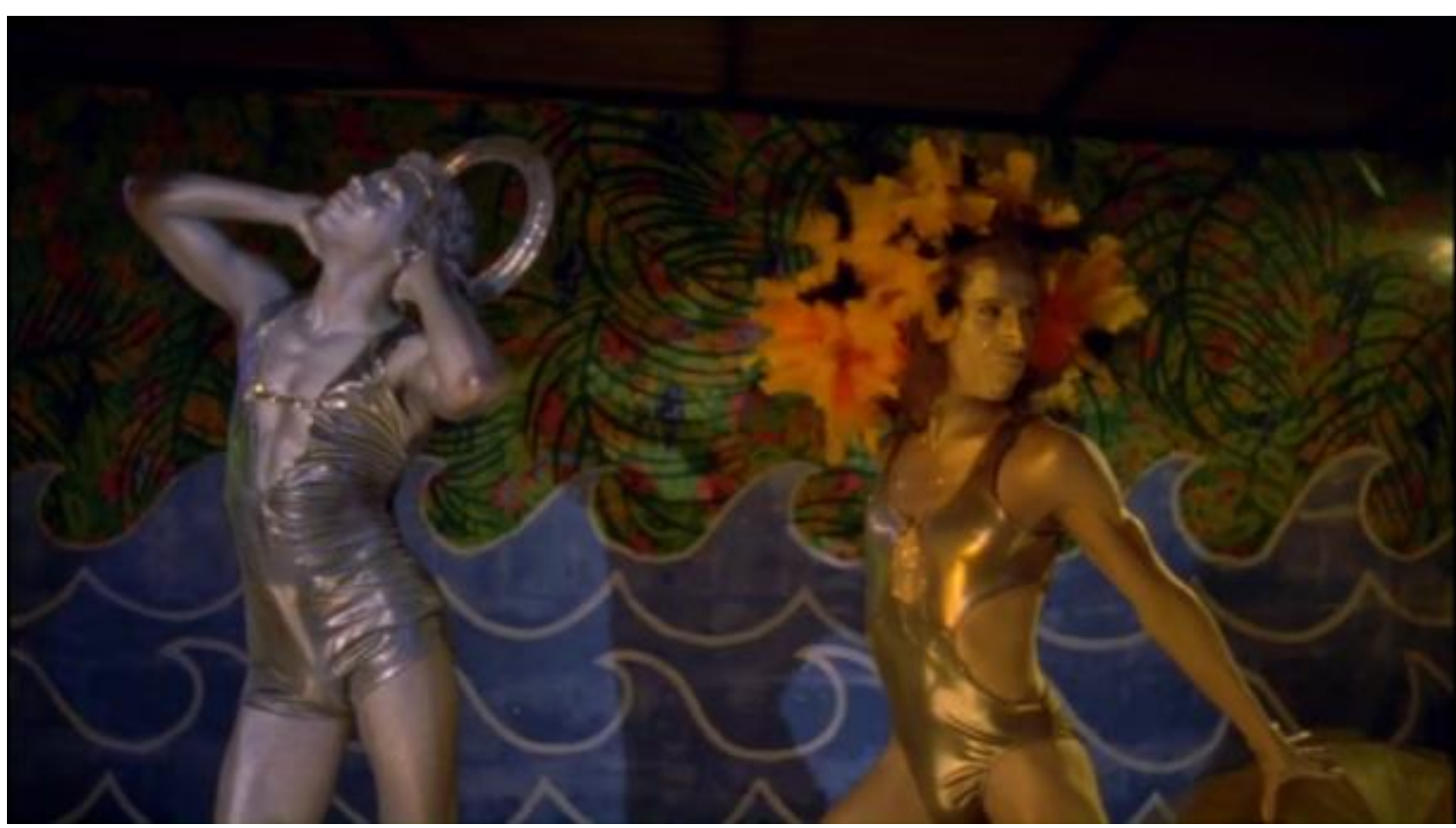

Fonte: Tatuagem (2013).

Figura 15 - Cena de apresentação de Clécio

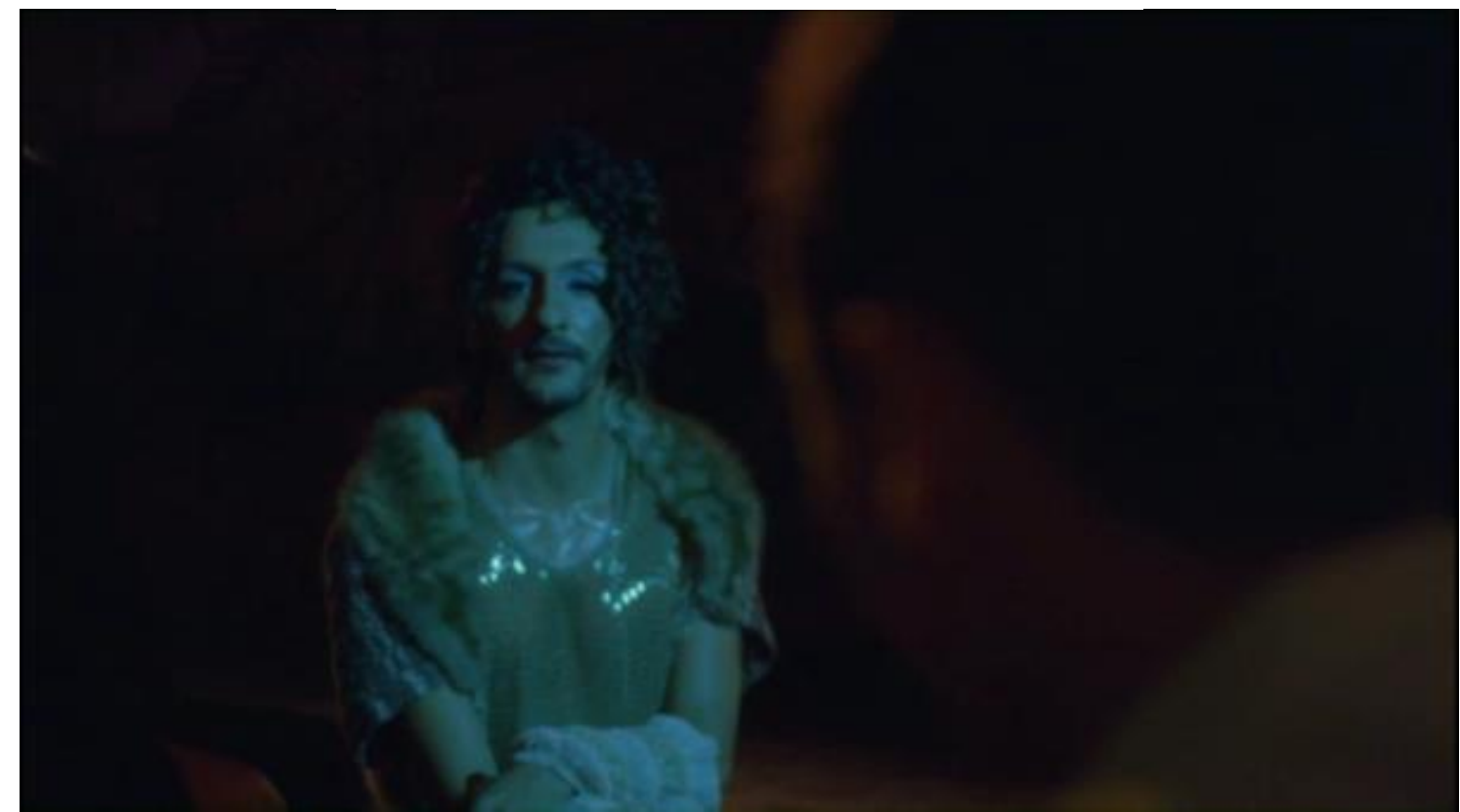

Fonte: Tatuagem (2013) 
Figura 16 - Cena de sexo do casal

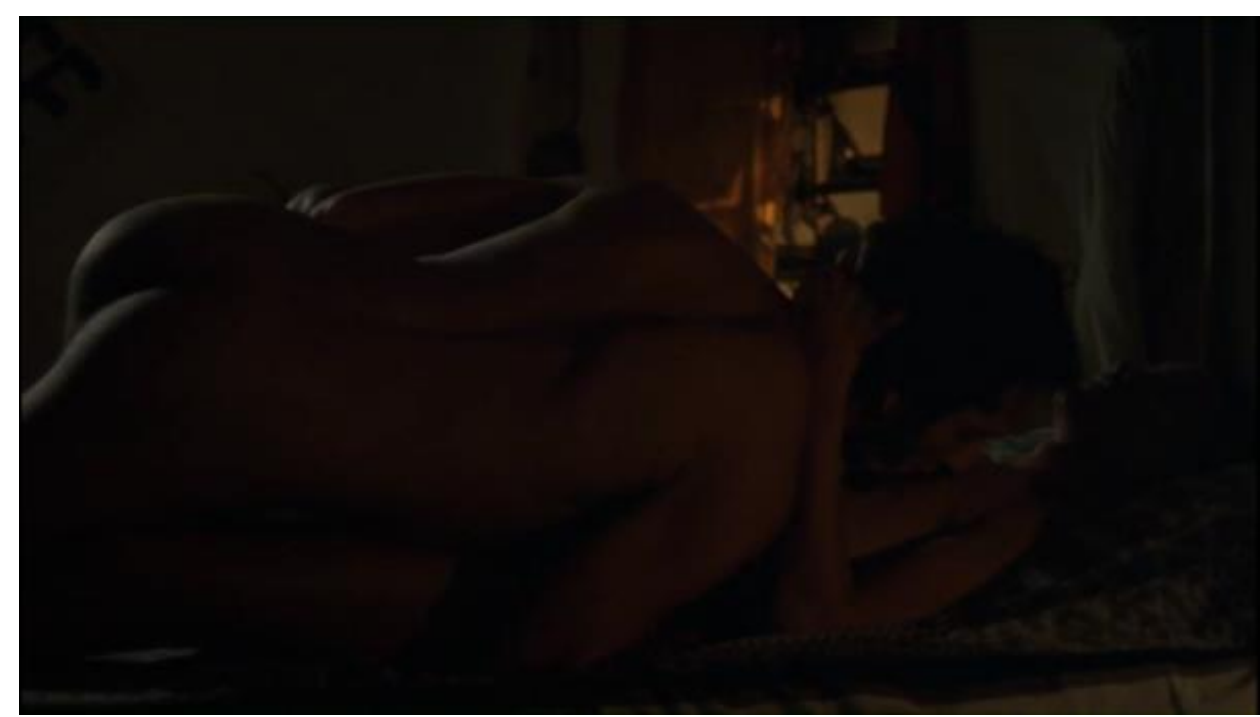

Fonte: Tatuagem (2013).

Figura 17 - Cena de performance artística

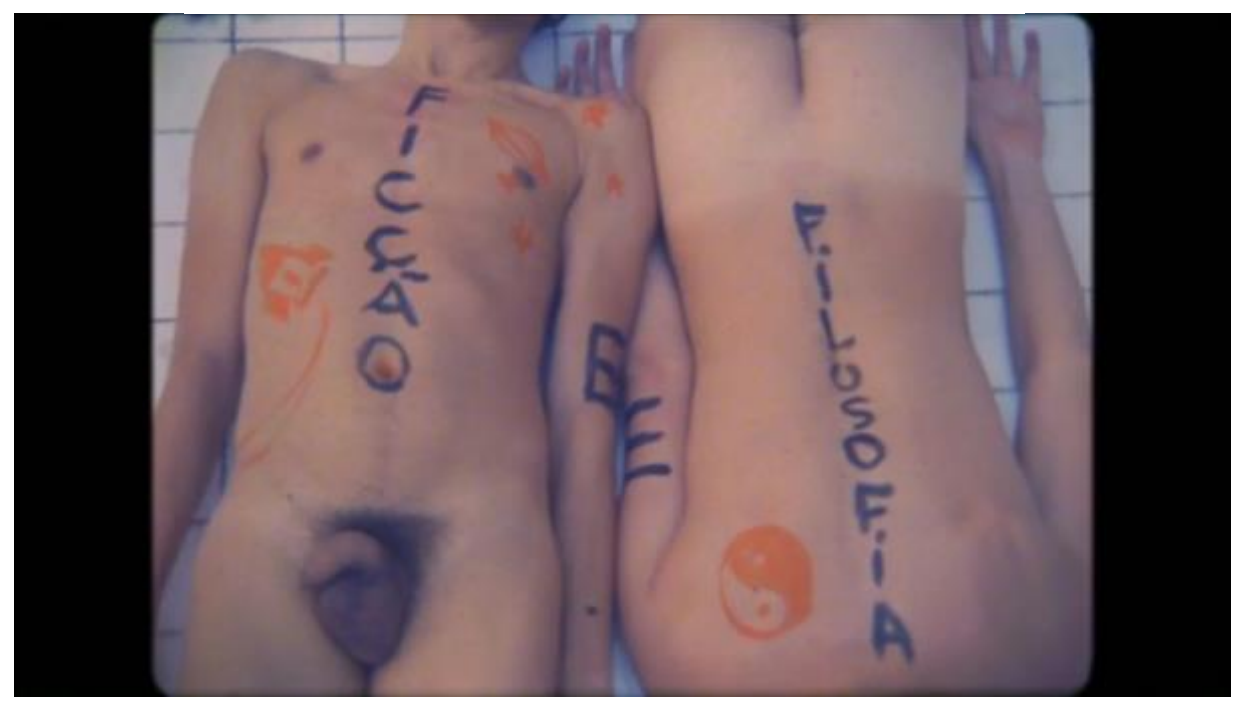

Fonte: Tatuagem (2013)

É percebido que, mesmo que os dois filmes tenham feito sucesso no Brasil e no exterior, Hoje eu quero voltar sozinho arrecadou mais do que o dobro do que arrecadou Tatuagem e atingiu um público muito maior também 6 . Isso se deve ao apelo mais popular de Hoje eu quero voltar sozinho, que tem uma narrativa parecida com outros filmes americanos e trata do seu tema com mais leveza do que Tatuagem, que é um filme que retrata questões

\footnotetext{
${ }^{6}$ Enquanto Hoje eu quero voltar sozinho arrecadou mais de dois milhões em bilheterias e atingiu um público de cerca de duzentos mil pessoas, Tatuagem arrecadou cerca de $\mathrm{R} \$ 430$ mil reais, tendo alcançado um público de mais de 44 mil pessoas (OCA ANCINE, 2015).
} 
de um ponto de vista da periferia pernambucana e que tem como objetivo questionar a discriminação do sexo, a opressão e a conquista de liberdade. Embora ambos os filmes falem sobre o amor entre dois homens, um deles vai mais contra os padrões do que o outro, e tem a temática tratada com muito mais profundidade e densidade. Isso teve consequência nas bilheterias, levando Hoje eu quero voltar sozinho a ter uma melhor recepção por parte do público.

\section{Considerações finais}

Mesmo que os dois filmes apresentem histórias de amor entre dois rapazes, a narrativa e o discurso que passam em tela são muito diferentes. Daniel Ribeiro, com Hoje eu quero voltar sozinho (2014), sua estreia no cinema como diretor, nos apresenta um filme de amor adolescente que se diferencia dos demais nesse gênero por apresentar como protagonista dessa história dois meninos, um deles deficiente visual. Retirando essa característica dele, todo o resto da narrativa apresenta clichês adolescentes. A homossexualidade é só um diferencial no filme. Para eles, isso vai sendo tratado naturalmente, o que pode representar para o espectador uma ilusão, pois isso não retrata a realidade de milhares de jovens que sofrem preconceito diariamente, que não são aceitos pelos pais, muitas vezes perdendo os amigos e sendo expulsos de casa. A falta de profundidade neste aspecto tem a função no filme de querer naturalizar o assunto e não ver problemas nisso, mas a partir do momento em que não é mostrada de nenhuma forma a real situação, isso pode ludibriar o público.

O filme segue também todos os padrões heteronormativos que a sociedade impõe aos gays para serem aceitos. Leonardo e Gabriel são meninos brancos, cisgêneros, de corpos magros e que não questionam de nenhuma forma as normas. Ambos são masculinizados, tendo as suas identidades sexuais completamente de acordo com o sexo cromossômico. Personagens negros e pobres são higienizados de cena, os únicos negros são uma das professoras e o aluno novo no final do filme. Isso tudo só dá forças ao sistema heteronormativo. Os protagonistas não têm "jeito de gay", seguem um modelo estético eurocêntrico e a relação íntima entre eles não passa de um beijo.

Em contraponto a Hoje eu quero voltar sozinho, Tatuagem é um filme onde a homossexualidade é essencial para a construção da história. 0 filme não trata tanto sobre preconceito aos gays, somente em algumas cenas isso é mostrado, como quando o filho de 
Clécio tem problemas na escola por ter um pai "veado". A história contada também é de amor, mas ela tem como plano de fundo uma época de opressão pela ditadura militar, fazendo com que seja discutido muito sobre a liberdade em todas as suas formas, como liberdade de expressão e liberdade sexual. Focar em um casal homoafetivo colabora para que seja passada a ideia de desconstrução das normas, de anormalidade às regras da sociedade que a trupe Chão de Estrelas representa. Tatuagem (2013) acaba, então, tratando com mais profundidade os temas, tendo mais maturidade narrativa do que o primeiro filme.

Como a quebra de padrões e a liberdade sexual são uns dos principais temas do filme, os personagens não seriam retratados de forma diferente. Paulete, Clécio e Fininha são todos homens cisgêneros, mas quebram algumas regras da heteronormatividade. Para causar mais incômodo ainda para os heteronormativos, o filme não tem pudores para mostrar o beijo gay ou o sexo entre dois homens, insinuando o sexo oral e a penetração anal de maneira quase explícita. Tatuagem apresenta também maior diversidade de etnias e uma realidade mais periférica do Brasil. Os protagonistas mesmo sendo brancos e dentro dos padrões de beleza não seguem tanto o modelo eurocêntrico, tendo características e aparências étnicas brasileiras.

Percebemos que, atualmente, no cinema brasileiro, a homossexualidade já é tratada com mais naturalidade. Mesmo assim, existem duas vertentes de representação dos homossexuais. Em uma delas, os homossexuais são retratados de acordo com os padrões heteronormativos, seguindo regras impostas culturalmente pela sociedade, enquanto a outra vertente procura justamente desconstruir essas normas, caracterizando-se por ser queer. Tatuagem tem as características de uma história queer, enquadrando-se nesse tipo de vertente. Já Hoje eu quero voltar sozinho legitima as posturas normativas, não questionando categorias de identidade de gênero, sexualidade e heteronormatividade, fora dos conceitos queer.

Ambas as visões de representação da homossexualidade não obtiveram tanta dificuldade para a produção dos filmes, devido ao incentivo de órgãos estatais, federais e a programas de incentivo à cultura, mas é nas bilheterias que a diferença de receptividade entre as duas formas surge. A popularidade de Hoje eu quero voltar sozinho nos cinemas foi muito maior do que Tatuagem. A forma como trata a temática, adaptando-se à heteronormatividade, fez com que Hoje eu quero voltar sozinho atingisse, além do público LGBTI+, héteros que só aceitam gays "afetados", como eles próprio dizem, quando podem rir deles e que não querem assistir a um filme que trata de questões polêmicas com mais 
profundida, questionando o próprio pensamento deles e apresentando um relacionamento homoafetivo de forma mais explícita como faz Tatuagem.

De que adianta então a popularidade para um filme LGBTI+ que fortalece os padrões normativos? Não é dessa maneira que enfrentaremos o preconceito e a discriminação que ainda geram centenas de mortos todos os anos. É preciso incentivar a produção de mais filmes queer no Brasil, que servirão como meio de educar o povo sobre o problema de sustentar normas conservadoras construídas culturalmente ao longo dos anos, que só contribuem para o crescimento de uma violência preconceituosa e discriminatória, impedindo o crescimento e avanço nas leis do país.

\section{Referências}

ALMEIDA, Miguel Vale de. A Teoria Queer e a Contestação da Categoria "Género". In: CASCAIS, António Fernando (org.). Indisciplinar a Teoria. Estudos Gay, Lésbicos e Queer. Lisboa: Editora Fenda, 2004.

ARAUJO, Joana. Caso Crivella X Bienal do Livro: censura ou proteção ao menor? Estado de São Paulo, São Paulo, 12 set. 2019.

BUTLER, Judith. Problemas de gênero: feminismo e subversão da identidade. Rio de Janeiro: Civilização Brasileira, 2003.

CASSETTI, Francesco; CHIO, Federico Di. Análisis de la televisión: instrumentos, métodos y prácticas de investigación. Barcelona: Paidós, 1999.

EXITOÍNA. Ancine volta atrás e retira apoio a filmes LGBT após ação de Bolsonaro. São Paulo, 16 set. 2019. Disponível em: https://exitoina.uol.com.br/noticias/cinema/ancinevolta-atras-e-retira-apoio-filmes-lgbt-apos-acao-de-bolsonaro.phtml. Acesso em: 24 out. 2019.

FOUCAULT, Michel. A história da sexualidade 1: a vontade de saber. 1 ed. São Paulo: Paz e Terra, 2014.

G1 RS. Mostra Queermuseu é desmontada em Porto Alegre e deve sofrer uma pausa até ser reaberta. Rio Grande do Sul, 10 out. 2017. Disponível em: https://g1.globo.com/rs/rio-grande-do-sul/noticia/mostra-queermuseu-e-desmontadaem-porto-alegre-e-deve-sofrer-uma-pausa-ate-ser-reaberta.ghtml. Acesso em: 24 out. 2019.

HALL, Stuart. A identidade cultural na pós-modernidade. 10 ed. Rio de Janeiro: DP\&A, 2005.

HERMANSON, Marcos. Relatório registra 420 vítimas fatais de discriminação contra LGBTs no Brasil em 2018. Brasil de Fato, São Paulo, 08 fev. 2019. 
HOJE eu quero voltar sozinho. Direção de Daniel Ribeiro. Produção: Diana Almeida e Daniel Ribeiro. São Paulo: Lacuna Filmes, 2014. 1 DVD (96 min.).

JOHNSON, Richard. Estudos Culturais: Uma introdução. In: SILVA, Tomaz Tadeu da (org.). 0 que é, afinal, Estudos Culturais? Belo Horizonte: Autêntica, 2010. p. 07-131.

MISKOLCI, Richard. A Teoria Queer e a questão das diferenças. In: CONGRESSO DE LEITURA NO BRASIL, (COLE) 16, 2007, Campinas. Anais[...] Campinas: ALB Associação de Leitura do Brasil, 2007. v. 1, p. 1-19.

OCA ANCINE. Filmes Brasileiros e Estrangeiros Lançados - 2013. Brasília, 2015.

PRECIADO, Beatriz. Manifesto contrassexual: práticas subversivas de identidade sexual. 2 ed. São Paulo: n. 1 edições, 2015.

SEDGWICK, Eve Kosofsky. A epistemologia do armário. Cadernos Pagu, Campinas, n. 28, p. 19-54, jan./jun. 2007.

SILVA, Tomaz Tadeu; HALL, Stuart; WOODWARD, Kathryn. Identidade e Diferença: a perspectiva dos estudos culturais. Trad. E org.: Thomaz Tadeu da Silva. Petrópolis: Vozes, 2014.

SOUZA, Alberto Carneiro Barbosa de. "Se ele é artilheiro, eu também quero sair do banco": um estudo sobre a coparentalidade homossexual. mar. 2008. 71 f. Dissertação (Mestrado em Psicologia) - Pontifícia Universidade Católica do Rio de Janeiro, Rio de Janeiro, 2008.

TATUAGEM. Direção: Hilton Lacerda. Produção: João Vieira Jr. Recife: REC Produtores, 2013. 1 DVD (110 min.).

\title{
Gay cinema in Brazil: the representation of gay men in Tatuagem and The Way He Looks
}

\begin{abstract}
This paper analyzes the representation of homosexuals in contemporary Brazilian cinema through the perspective of Queer Cinema, focusing on the films Tatuagem (2013) and The Way He Looks (2014). The analysis methodology used is the Culture Circuit proposed by Johnson (1999), mixed with the textual analysis according to the conceptions of Cassetti and Chio (1999). We realize from the analysis that there are two strands of representation of homosexuals in Brazilian gay cinema, one more concerned with following heteronormative patterns and another that seeks to deconstruct these norms, being characterized as queer.
\end{abstract}




\section{Keywords}

Representation; Cinema; Sexuality; Identity; Queer Theory

\section{Autoria para correspondência}

Rodrigo Quevedo Fagundes

rodrigofagundes95@gmail.com

\section{Como citar}

FAGUNDES, Rodrigo Quevedo; LISBÔA FILHO, Flavi Ferreira. O cinema gay no Brasil: a representação dos homossexuais em Tatuagem e Hoje Eu Quero Voltar Sozinho. Intexto, Porto Alegre, n. 52, e-99876, jan./dez. 2021. DOI: http://dx.doi.org/10.19132/1807-8583202152.99876

Recebido em 26/01/2020

Aceito em 01/06/2021 